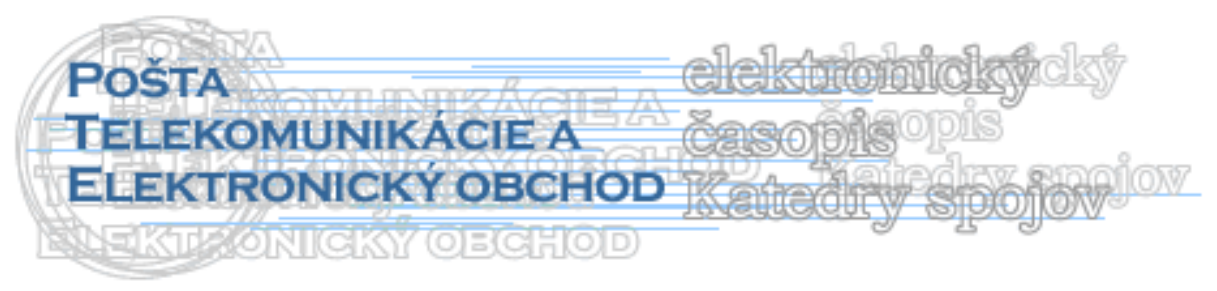

\title{
IMPLEMENTÁCIA RFID SYSTÉMOV V PROSTREDÍ SCM
}

\author{
Ivan Michálek ${ }^{1}$, Juraj Vaculík ${ }^{2}$
}

„Slová bez činov sú vrahmi idealizmu““

\section{- Herbert Hoover, 31. prezident USA}

\section{ÚVOD}

Horeuvedený citát poukazuje na to, čo väčšina l'udí robí v súvislosti s RFID technológiou : teoretizujú o úžitkoch a benefitoch. Prijímanie adekvátnych opatrení a implementácia rádio frekvenčného systému sa považuje za riskantnú a častokrát vel'mi zložitú. V tejto kapitole sa predstavujú niektoré druhy stratégií, ktoré spolupôsobia pri procese implementácie RFID technológie do existujúcej infraštruktúry organizácie. Predmetom diskusie tejto sekcie bude :

- spôsoby testovania RFID v prostredí prototypu,

- predstavenie Návrhu pre Six Sigma výskum (Design for Six Sigma Research DFSSR) pre oblast' testovania RFID technológie,

- spôsob uskutočnenia DFSSR pre oblast' testovania a vyhodnotenia prototypov,

- ostatné metódy testovania RFID prostredia.

Odporúčané kroky pre proaktívnu implementáciu RFID systémov sú :

- tvorba štúdie ROI (Return on Investments : návratnost' investícií) pre RFID,

- výber správnej RFID technológie,

- predpokladané technické problémy spojené s implementáciou RFID,

- riadenie a správa informačných technológií (IT) a prvkov ich infraštruktúry,

- správa dát,

- integrácia a prepojenie s koncovými (back-end) aplikáciami,

- skúšobný projekt pre získavanie skúseností.

\section{Tvorba štúdie ROI pre RFID}

Tento krok sa javí ako logicky opodstatnený pre impementáciu akejkol’vek technológie, RFID nevynímajúc. Analýza ROI (návratnost' investícií, miera rentability) je

\footnotetext{
${ }^{1}$ Ing. Ivan Michálek, Žilinská univerzita, fakulta PEDaS, externý doktorand, mail: imichalek@ centrum.sk

2 Doc. Ing. Juraj Vaculík, Žilinská univerzita, fakulta PEDaS, mail: juvac@ @pedas.uniza.sk, vedúci oddelenia EKaS, katedra spojov. Tf: +421 415133132
} 
bežne používaná pre odôvodnenie výšky investícií, resp. vynaložených nákladov v takto nákladných systémoch. V dôsledku mandátov, ktoré v Spojených štátoch direktívne predurčujú top-dodávatel'om v logistickom ret'azci (Wal-Mart, DoD) používat' pasívne prvky RFID, opodstatnenost' nákladov / investícií, resp. miera rentability nie je realizovaná pred samotnou implementáciou. Z titulu týchto mandátov spadá proces implementácie RFID technológie do kategórie nákladov z podnikatel'skej činnosti a nie ako bežný obchodný výdavok. Miera rentability by sa ale minimálne mala vykonat' s ohl'adom na ocenenie prípadnej straty pri riešení implementácie RFID, resp. určení horizontu, kedy sa investícia splatí.

\section{Výber správnej RFID technológie}

Rádio frekvenčná identifikácia sa vkladá do priemyselných procesov už niekol'ko rokov. Pre efektívnejšie ohodnotenie potenciálneho využitia a implementácie tejto technológie sa vytvoril prístup nazývaný DFSS, tj. návrh pre Six Sigma. DFSS má mnoho aplikácií, napr. meranie a analýza procesu implementácie RFID technológie, koncepcia testovacieho prostredia $\mathrm{v}$ oblasti skladového hospodárstva, resp. rozvoj a optimalizácia podmienok pre najefektívnejší proces snímania.

RFID sa nazýva aj čiarovým kódom d’alšieho desat'ročia. Najväčšou výhodou RFID technológie je, že nevyžaduje priamu viditel'nost' medzi snímačom a štítkami. S RFID systémom je možné okamžite a exaktne identifikovat' obsah zásielky pozostávajúcej z niekol'kých položiek s pripevneným štítkom bez toho, aby sa predmetná zásielka musela otvárat'.

\section{Stručná charakteristika RFID systému}

RFID systém pozostáva z rádio frekvenčného snímača a štítku. Inými slovami, štítok môže byt' vložený, resp. zapustený do snímaného objektu. Anténa snímača v RFID systéme vysiela rádiové signály. Tieto signály prijíma anténa štítku, ktorá môže byt' nabíjaná batériou alebo rádio frekvenčnou energiou vychádzajúcou zo snímača. Štítky reagujú osobitým kódom, ktorý je naprogramovaný v mikročipe štítku. Po prijatí a dekódovaní signálu zo štítku posiela anténa snímača dáta to centrálneho počítača cez štandardné rozhranie. Táto informácia je potom sprístupnená $\mathrm{v}$ databáze. Výhodou tejto technológie je možnost' snímania bez podmienky priamej viditel’nosti medzi snímačom a šítkom a zároveň možnost' snímania viacerých štítkov jedným snímačom naraz (antikolízia). V tejto sekcii použijeme simulovaný sklad ako prostredie pre vykonanie DFSSR techník.

\section{Six Sigma metodológia}

Metodológia charakterizovaná $\mathrm{v}$ tejto kapitole je definovaná ako Integrovaný návrh pre Six Sigma. DMADO je akronym pre návrh (design), meranie (measure), analýzu (analyse), rozvoj (develop) a optimalizáciu (optimize). Plánovacia funkcia je kategorizovaná ako definovanie ciel'ov a stanovenie správnych meracích parametrov. Predvidacie funkcie sú analýza realizovatel'ných volieb, návrhy experimentov vedúcich k rozvoju, identifikácia nezhôd, opätovná analýza volieb vychádzajúca zo skutočného výkonu a záverečná tvorba finálneho návrhu, ktorý splńa stanovené ciele. Vystupovacie funkcie sú optimalizácia výkonu návrhu a overenie, či je prototyp funkčný. Tento nový prístup k výskumu pomáha premostit' medzeru medzi akademickým prostredím a priemyslom. Experimenty a analýzy budú vykonávané na základe explicitných vedeckých metodológií. 


\section{P teoretický model}

V tejto časti je definovaný výskumný rámec. Návrh pre Six Sigma výskum (DFSSR), ktorý je založený na myšlienke bežného funkčného prototypu, vyžaduje vývojárske tímy pre potreby fáz plánovania, predvídania a realizácie. Idea využitia 3P (planning, predict, perform) je chytl'avá a je využívaná pre vedecké vzdelávanie a projektové riadenia. Tento 3P model inovuje tento konkrétny výskum tým, že predstavuje efektívny komunikačný nástroj pre uzavretie, resp. obalenie DFSSR rámca. Z pohl'adu efektívnejšej aplikácie RFID technológie v prostredí priemyslu je potrebné uskutočnit' sériu experimentov za účelom uvedenia teoretickej schémy RFID systému do reálneho prostredia. Six Sigma metodológia pomáha vytvorit' vedeckú procedúru a uistit' sa, že sa jedná o optimálnu schému pre vymedzené skladové prostredie. Využívame tento rámec tak, aby operácie mohli identifikovat' stav projektu a preskúmat' detailné procesy vo vnútri rámca. DFSSR procesné kroky sú usporiadané a organizované $\mathrm{v} 3 \mathrm{P}$ rámci, ako je to znázornené na obr. 1. Zistené výsledky môžu byt' použité za účelom efektívnej implementácie technológie vo vymedzenom prostredí. Táto metodológia sa zároveň zaoberá definovaním správneho prototypového prostredia, testovaním RFID podsystému a testovaním integrovaného systému pre účely prototypového prostredia.

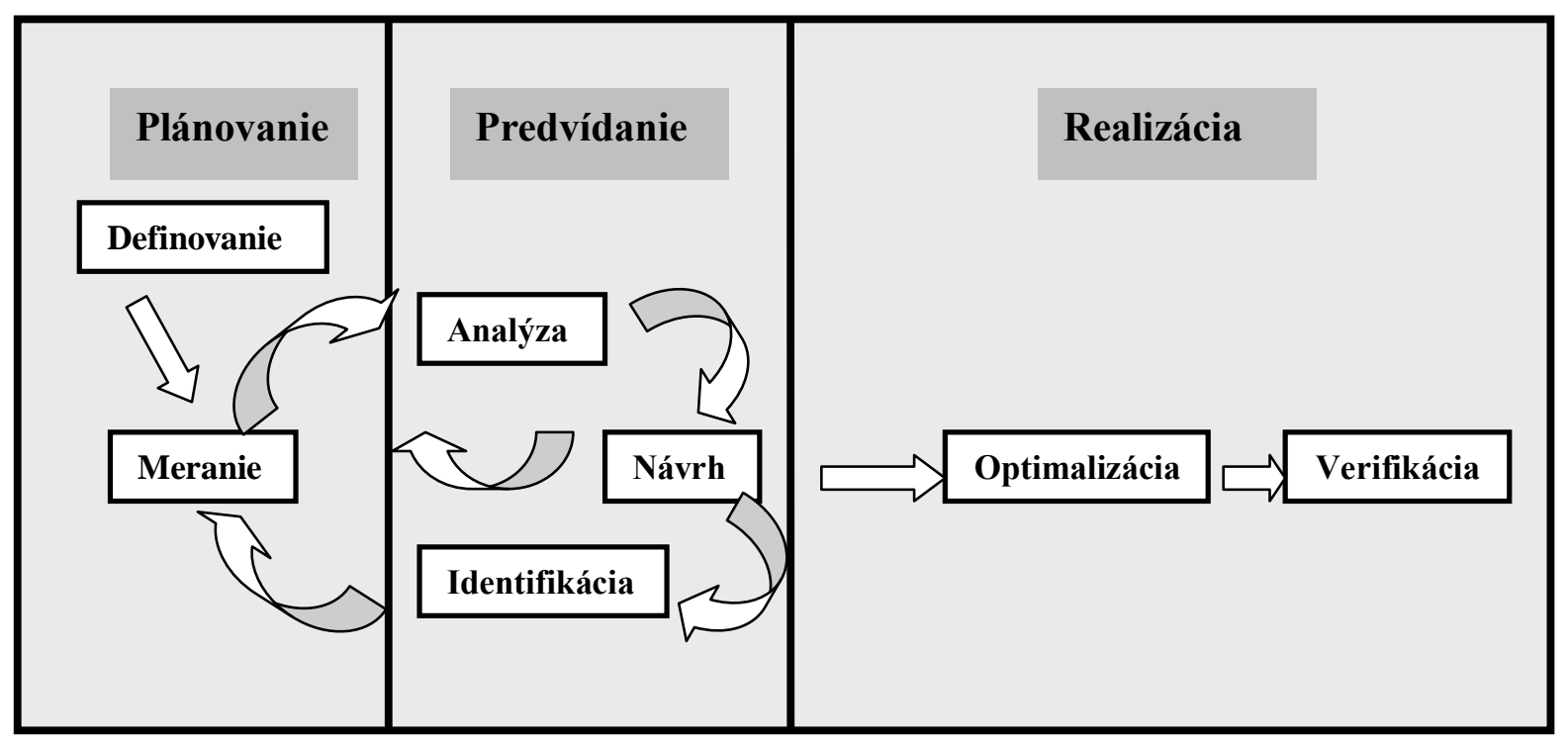

Obrázok 1. DFSSR 3P metodologický rámec

\section{AD 1./ Plánovanie}

V tejto fáze je potrebné identifikovat' kritickú cestu pre informáciu aj pre materiálový tok. Prvá vec, ktorú treba $\mathrm{v}$ rámci plánovacej fázy vykonat' je zadefinovat' problém v reálnom prostredí; napríklad : aký druh výrobku sa zaskladňuje, aká je frekvencia dodávania na sklad, atd’. Tieto veci úzko súvisia s test-návrhom pre skladové hospodárstvo.

\section{AD 2./ Definovanie}

Vo fáze definovania je nevyhnutné spracovat' reálne požiadavky prostredia do prostredia testovacích parametrov. Teoretický model vo fáze návrhu a analýzy by mal 
poukazovat' na svoju nevyhnutnost' a opodstatnenie pre potreby budúcich experimentov. $\mathrm{V}$ tomto kroku charakterizujeme schému procesov založenú na vstupných dátach, pochopenie úloh a vzt'ahov medzi jednotlivými činnost’ami a analýzu materiálového toku. Krok zadefinovania je spomenutý už v prvej fáze - plánovaní. Dôležité v tejto fáze je identifikovat' jasný materiálový tok ako základ pre predvídaciu a realizačnú fázu. Obrázok 2 poukazuje na tento 3P myšlienkový proces.

\section{AD 3./ Meranie}

Viacúčelová skladová RF architektúra predstavuje celkový RFID implementačný systém pozostávajúci z troch hlavných častí : RFID hraničnú vrstvu, RFID fyzickú vrstvu a podnikovú integračnú siet'. RFID fyzická vrstva spája ostatné dve časti. RFID systém je navrhnutý pre spracovávanie toku štítkov, resp. snímaných dát prichádzajúcich $\mathrm{z}$ jedného alebo viacerých RFID snímačov. Hraničná vrstva má schopnost' filtrovat' a zhromažd'ovat' dáta pred ich odoslaním k požadovanej aplikácií. Napríklad, činnost' (snímanie štítku) je spustená v okamžiku pohybu snímanej položky alebo v prípade zaznamenania novej položky v dosahu čítacej zóny snímača. RFID hraničné servery filtrujú a zbierajú dáta zo štítkov na jednotlivých miestach a zasielajú ich cez internet d'alej do tretej vrstvy : podnikovej integračnej vrstvy (siete).

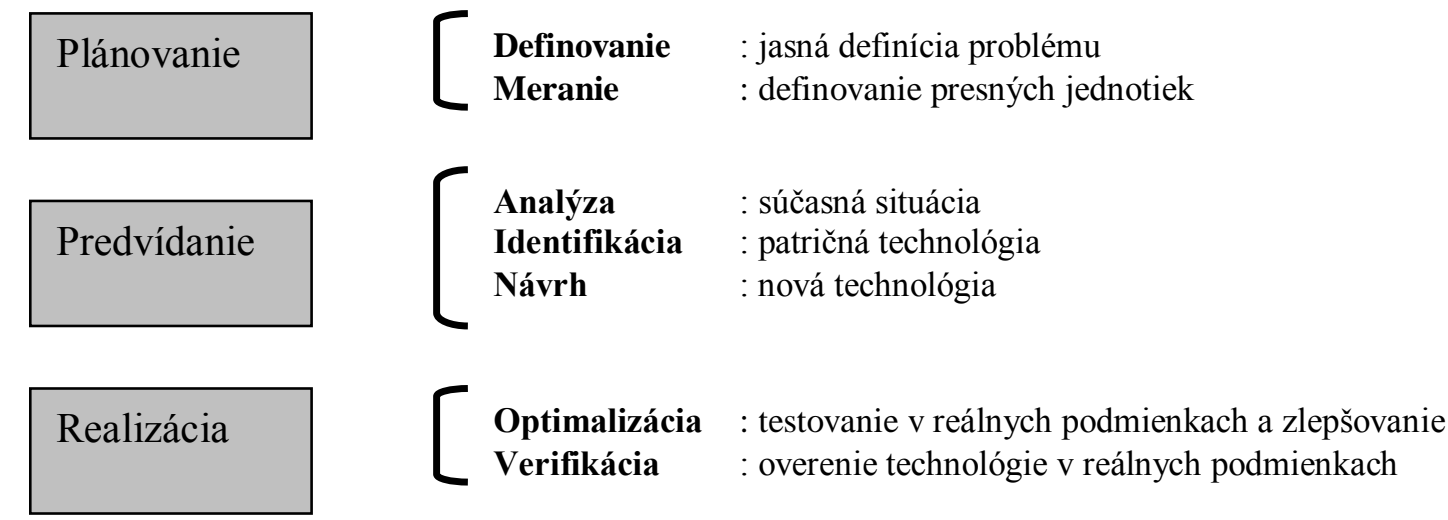

\section{Obrázok 2 3P myšlienkový proces}

Sústredené dáta sú identifikované separátne podl’a druhu činnosti, tj. či sa jedná o pohyb alebo stacionárnu činnost'. Tento rozdiel delí použitie RFID antény do dvoch typov zariadení : snímač pripevnený na skladovej vstupnej bráne a mobilný snímač pre účely sledovania pohybu zásob. Základá zásada pre skladový portálový distribučný systém je neustále sa prispôsobovat' možným zmenám v sieti. Portálové zariadenia poskytujú spoločenstvu užívatel'ov možnost' prístupu k dátam o rozmiestnení zásob v reálnom čase, tak ako aj možnost' doručit' a vyhl'adávat' osobné údaje. Poskytuje to externým zákazníkom a partnerom bezpečný prístup $\mathrm{k}$ dátam.

RFID skladový systém delíme na tri vrstvy : fyzická vrstva, logická vrstva a integračná systémová vrstva. Každá vrstva sa skladá z rôznych komponentov. Závisí to od funkcií, ktoré RFID systém vyžaduje. Pochopením toku v sklade je možné presne definovat' druhy RFID štítkov a antén.

V skratke, RFID implementácia do akéhokol'vek procesu vyžaduje dve alebo tri vrstvy. Fyzická vrstva predstavuje výkonnú čast' procesov a logická vrstva zaznamenáva a filtruje dáta a má navyše integrujúcu funkciu. 


\section{AD 4./ Predvídanie}

Hlavnou otázkou v tejto fáze je analýza výsledku a procesu skúšanej RFID činnosti. Je zrejmé, že výsledky experimentov alebo testov sú pre spoločnosti, ktoré sa usilujú implementovat' RFID technológiu do svojej infraštruktúry, vel'mi dôležité. Situácia môže byt' dost' odlišná u jednotlivých spoločností. V súčinnosti s reálnym prostredím a požiadavkymi na umiestnenie by testy mali prebiehat' vhodným a efektívnym spôsobom.

\section{AD 5./ Analýza}

Tok dát $\mathrm{v}$ rámci distribučného procesu predstavuje jeden $\mathrm{z}$ komponentov návrhu schémy RFID skladu. Je zahrnutý vo fáze experimentálneho návrhu. Ciel'om tejto aktivity je definovat' vstupné a výstupné dáta za účelom potvrdenia toku dát a ich fyzického toku. Dátové štandardy sa môžu v rámci logistického ret'azca jemne zmenit', ked'že môže dôjst' k sformátovaniu, resp. usporiadaniu dát. Pracovný tok spolu s dátovým tokom je generovaný výrobným tokom smerom od fyzickej $\mathrm{k}$ logickej vrstve. Všetky dáta vybrané distribučným procesom sú generované RFID nástrojmi vrátane RFID štítkov na každej palete, resp. anténou na každom portále. Preto umiestnenie RFID nástrojov vplýva na presnost' distribučného procesu, ktorý formuje individuálny dátový tok podl'a postupu práce. Umiestnenie RFID antény, resp. senzora bude prejednané neskôr.

\section{AD 6./ Návrh}

Vzhl'adom na nízke náklady a vysoký objem informačného toku sa pre vytýčenú skladovú simuláciu zvolili pasívne štítky. Anténa, resp. senzor poukazuje na nástroj, ktorý je pripojený cez siet' alebo RF komunikačné médium ku iným senzorom v sieti. Umiestnenie týchto senzorov v sklade súvisí bud' $\mathrm{s}$ ich prostredím alebo $\mathrm{s}$ tokom dát, ktorý sa zistí pevne pripevnenou anténou na vstupnej bráne. Pre zmeranie presnosti a efektívnosti RFID výkonu v simulovanom skladovom prostredí sa využíva pomer vyhodnocujúci vzt'ah medzi výkonom a efektívnost'ou RFID. Tento pomer je definovaný ako $\sigma_{\mathrm{r}}$, ktorý vyjadruje jednoduchý vzt’ah medzi vstupnými a výstupnými dátami :

$\boldsymbol{\sigma}_{\mathbf{r}}=\boldsymbol{\alpha}_{\mathbf{1}} / \boldsymbol{\beta}_{\mathbf{0}}$, kde $\sigma_{\mathrm{r}}=$ pomer; $\alpha_{1}=$ vstup; $\beta_{0}=$ výstup.

Tento pomer nám však vyjadruje len priemerný výkon RFID snímatel'nosti. Vstupné komponenty vyžadujú pre vyhodnotenie prostredia a výkonu presné dáta. V rámci simulácie sa môže pre účel komparácie vstupných dát a dátového toku použit' výkon skúšobného testu (benchmark). Rozličné množstvo pracovného toku reflektuje rozličné dátové toky v sklade, ale benchmark nám poskytuje spol'ahlivé dáta pre potreby merania rozličných skladových prostredí a pracovných tokov. V optimalizačnom kroku využijeme prípadovú štúdiu $\mathrm{k}$ ilustrácií tejto teórie.

\section{AD 7./ Realizácia}

Po predchádzajúcich fázach experimentov a aplikačných návrhov bude vykonaná záverečná štúdia. V tejto fáze je potrebné dokázat' opodstatnenost' zvoleného návrhu pomocou plánovania experimentov DOE (Design of experiments) a optimalizácie výkonnosti systému podl'a zadaných nastavení. 


\section{AD 8./ Optimalizácia}

Vychádzajúc $\mathrm{z}$ nášho teoretického modelu, budú v tejto časti vykonané experimenty s ohl'adom na optimálnu schému a efektívnost' zariadení. Ako nosná čast' štatistickej analýzy Six Sigma metodológie sa použije ukazovatel' DOE. Ten umožňuje súčasne zohl'adňovat' niekol'ko nezávislých premenných veličín (faktorov) v rámci jedného experimentu bez nutnosti neustáleho vyhodnocovania všetkých možných kombinácií. Pre experiment 1 sa použili dve nezávislé premenné a jedna závislá premenná veličina. Dve nezávislé veličiny predstavujú umiestnenie štítka a počet antén. Závislá premenná je snímatel’nost' štítka. Pozorované výsledky experimentu majú dopad na nezávislú premennú.

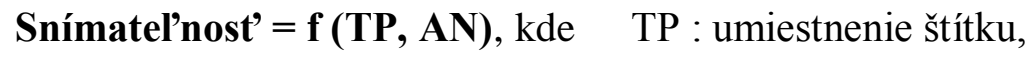

AN : počet antén.

Pre experiment 2 potrebujeme regulovat' jednu premennú veličinu dovtedy, kým dosiahnuté výsledky nebudú vyjadrovat' plnú, $100 \%$ snímatel'nost' z titulu požiadavky zákazníka dosahovat' predmetnú hodnotu. Model experimentu je vyjadrený nasledovne :

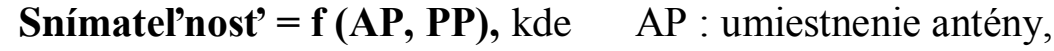

PP : umiestnenie brány.

Ak vykonávame plne faktoriálny experiment, reakcia zohl'adňuje všetky možné kombinácie experimentu. $Z$ dôvodu vel'kého množstva možných kombinácií v plne faktoriálnom experimente sa vyžaduje dvojúrovňový faktoriálny experiment. Experiment 1 je dvoj faktorový, dvojúrovňový experiment. Špecifické situácie, pre ktoré sa aplikuje DOE majú vplyv na počet zvolených faktorov a úrovní. Experiment 1 by mal počítat' so systematickým pozorovaním danej vlastnosti pri regulovaných podmienkach. Tým pádom bol experiment vykonaný nasledovne :

- umiestnenie štítku : hore, po stranách,

- počet antén : jedna anténa a dve antény (na každej strane portálu; dve antény sa použili pri jednom pokuse v rámci jedného experimentu).

Experiment 2, pri ktorom sa testovala snímatel'nost' štítkov a výkon, bol vykonaný tak ako experiment $1, \mathrm{~s}$ nasledovnými premennými :

- umiestnenie antény : dve antény v rovnakej výške po každej strane, resp. v dvoch rôznych výškach,

- vzdialenost' medzi portálmi.

\section{AD 9./ Verifikácia}

Existuje niekol'ko spôsobov, ako optimalizovat' súčasnú návrhovú schému za účelom zlepšenia presnosti snímania. Pri vykonanom experimente 1 klasifikujeme umiestnenie štítku na palete, resp. polože tromi spôsobmi : na vrchu, vpredu a na bočnej stene objektu. Výkon je pre každú kategóriu ale odlišný. Pri spätnej rekapitulácií, s ohl'adom na podmienky polarizácie a magnetického pol’a sa javí ako najlepšie umiestnenie štítku na bočnej stene objektu, resp. palety. 


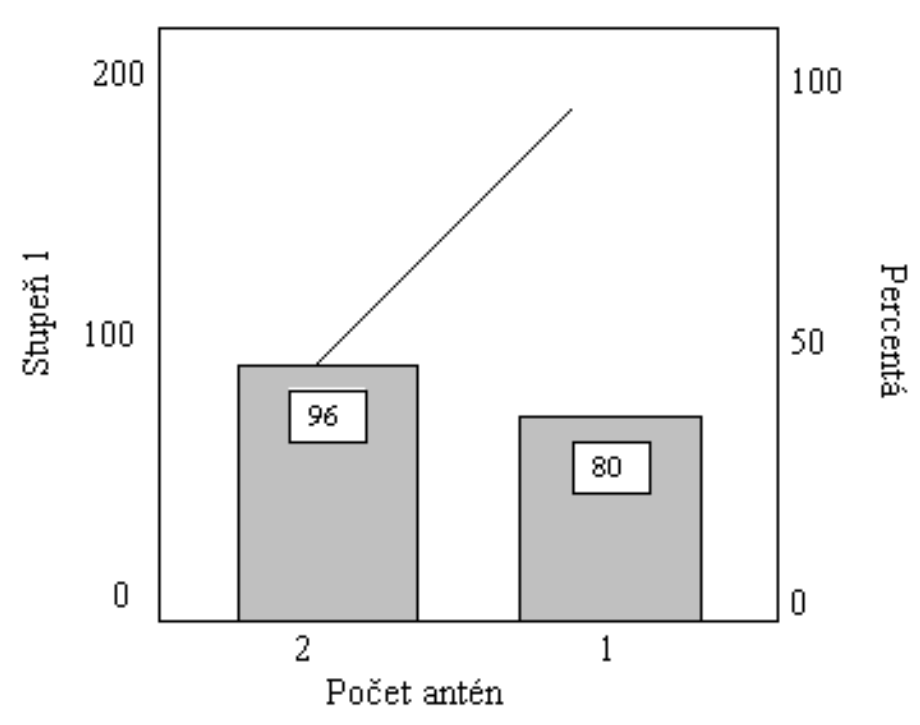

\section{Obrázok 3 Stupeň snímania v závislosti od počtu antén}

V porovnaní s výsledkami u ostatných kategórií je snímatel’nost' štítka umiestneného na bočnej stene objektu na úrovni 60 \% spokojnosti zákazníka. Tento výkon samozrejme nie je vel'mi uspokojivý. Výraznú zmenu do procesu prináša zmena počtu antén. Experiment 1 prebiehal s 1 anténou pri snímaní 10 položiek. Snímatel’nost' štítkov bola na úrovni asi $80 \%$ v porovnaní s takmer $100 \%$ pri použití 2 antén. Stupeň snímania v závislosti od počtu antén je uvedený na Obrázku 3.

Čo sa týka experimentu 2, vplyv umiestnenia štítka na model je podobný ako $\mathrm{u}$ experimentu 1. Rozličné efekty spôsobuje $\mathrm{v}$ tomto prípade umiestnenie antény. Experiment predpokladá, že anténa umiestnená $\mathrm{v}$ rozličných horizontálnych rovinách má pozitívny vplyv na snímatel'nost'. Nehorizontálne umiestnená anténa má pozitívny vplyv pri rastúcej vzdialenost' medzi anténami. Celkovo môžeme teda povedat', že dôležitými faktormi ovplyvňujúcimi efektívnost' snímania sú vzdialenost' štítkov a nehorizontálnych antén.

\section{Záver}

Reakčný čas antény a štítkov bol takmer identický pri oboch prípadových štúdiach, resp. experimentoch. Môžeme predpokladat', že miera snímatel'nosti dosiahne plné očakávania za určitých vytýčených špecifikácií :

- plná snímatel'nost' je v rozmedzí 1 - 1,5 m v prípade pevného uloženia antén v rovnakej horizontálnej výške na oboch stranách brány,

- plná snímatel'nost' je v rozmedzí 2 - 2,5 m v prípade pevného uloženia antén v rôznej výške po stranách brány,

- štítky pripevnené k snímaným objektom musia byt' postranne umiestnené alebo priamo smerom k anténam, pokial' chceme splnit' horeuvedené požiadavky na plnú snímatel'nost'.

Frekvencia, vzdialenost', uhly, druhy štítkov, umiestnenie, uloženie, vplyvy vlhkosti, druhy materiálov $($ kovy,...) - všetky tieto elementy podstatnou mierou ovplyvňujú snímatel'ost' štítkov. Efektívna snímacia zóna bola predmetov analýzy, ktorej vizuálny výstup je zobrazený na obr. 4, resp. 5. Dátové body na grafe poukazujú na náhodné 
odchýlky ale z grafu zároveň vyplýva, že najefektívnejší rozsah pre anténu leží $0,5-1 \mathrm{~m}$ od stredovej čiary. Stípec na pravej strane poukazuje na snímatel'nost'. Experiment vychádzal z 10 štítkov na palete. Dosiahnutá snímatel’nost' bola $90 \%$ a viac.

Súhrnne môžme konštatovat', že pre dosiahnutie hodnoty snímatel'nosti na úrovni 90 $\%$ a viac boli zahrnuté aj d'alšie dôležité faktory:

- umiestnenie štítku,

- vzdialenost' medzi anténami (v prípade, že máme viac ako jednu anténu),

- primeraný čas zastavenia pri prechode vstupnou bránou skladu (najmenej tri sekundy),

- zmena pozície antény.

Využitím SixSigma metodológie sa zvyšuje efektívnost' testovacích procedúr a schém pri impelemtácií RFID technológie do zabehnutej infraštruktúry organizácie.

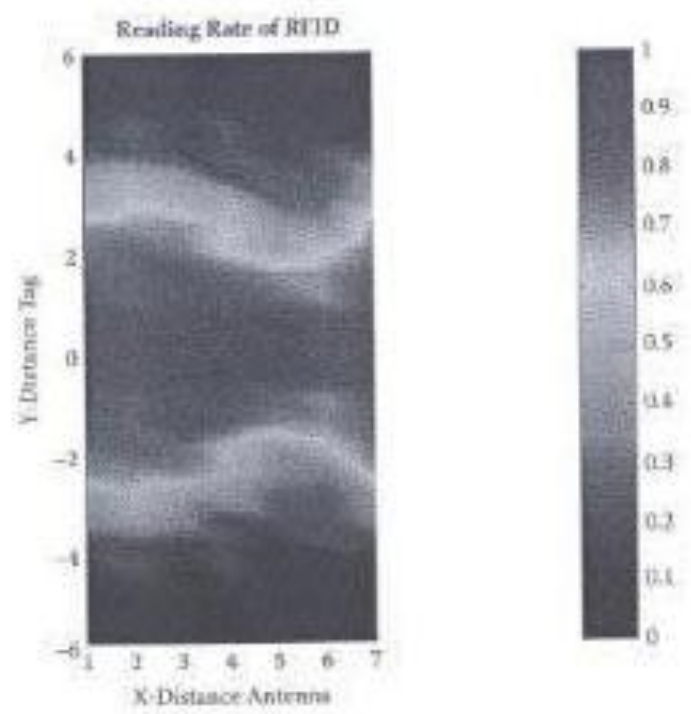

Obrázok 4 2D graf znázorňujúci efektívnu snímaciu škálu

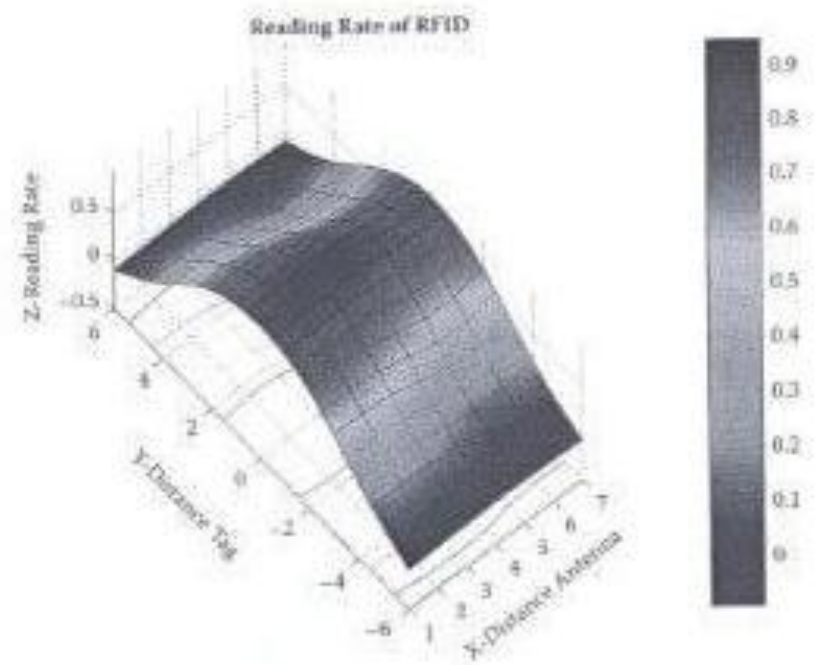

Obrázok 5 3D graf znázorňujúci efektívnu rýchlost' snímania 


\section{Literatúra}

[1] JONES, ERIC, CHUNG, CHRISTOPHER : RFID in Logistics: A Practical Introduction, ISBN 978-0849385261, 2007,

[2] BREYFOGLE, F. : Implementing Six Sigma : Smarter solutions using statistical methods, 2nd ed., New York : John Wiley \& Sons, 2003

[3] MYERSON, JUDITH : RFID in the Supply Chain: A Guide to Selection and Implementation, ISBN 978-08493301086, 2007

\section{Grantová podpora}

Projekt aplikačného výskumu - 4/2045/08 - Aplikácie technológie RFID pre vybrané poštové procesy na podmienky HSS 